\title{
Knowledge and Competitiveness in the Motor Insurance Sector
}

\author{
Jarosław Wenancjusz Przybytniowski \\ Correspondence: Jarosław Wenancjusz Przybytniowski, The Jan Kochanowski University, Correspondence: ul. \\ Świętokrzyska 21, 25-406 Kielce, Poland.
}

Received: October 30, 2016

doi:10.11114/bms.v3i2.2454

\author{
Accepted: June 1, 2017 \\ Online Published: June 1, 2017 \\ URL: https://doi.org/10.11114/bms.v3i2.2454
}

\begin{abstract}
The main purpose of this paper is to examine the relationship between the level of individuated customer knowledge and the quality of customer service in the motor insurance sector using the Servqual method. Based on the above objective, the author has accepted the thesis that knowledge is an important factor influencing the increase of quality of services provided in the motor insurance sector. In the article the author used the knowledge in the literature and conducted the analysis of statistical data on a selected group of respondents in the area of Podkarpackie and Lubelskie Province in the years 2015-2016.
\end{abstract}

Keywords: knowledge, customer awareness, Insurance service quality

\section{Introduction}

Quoting romantic Polish, poet and writer A. Mickiewicz: ,knowledge we can learn from other, but wisdom we must learn themselves". „Science and money others you will enrich, wisdom you must itself own himself." „Sage ordinary people from the conversation assesses and exceptional men learns of silence".

Wisdom is the sum of knowledge and good. Therefore Seneka (1961), ,recognized 'wisdom for superior excellence of the human soul'. So understood wisdom is training. If we want to think about their own future, we need to go back to the old idea of education. The prerequisite for this is re-arrival times proper training. In the meantime, looking at present the education process this it currently technical character. It was reduced mainly to the formation of skills to respond to questions. Not significance of these features that are necessary for life in contemporary, globalised technical civilisation. This type of training should be supplemented by the competence and qualification, as well as another dimension or existential, understood yet by the older generation trainers. Remember that the essence of education is and will be shaping the human and acquire new ways of self-fulfilment, whether meanings and value of life of every man. The same meaning training must be directly related to the meaning of life. According to M. Horkheimer (2011) training ,,... should be understanding of what celebrates us as people and not only as members of the public industrial', i.e., training should be a harmonious and comprehensive. May not be restricted only to the skills to communicate and operate and the use of electronic equipment (e.g. tablet, your computer). Next to the physical development or congenital advantages of intellectual training must include at the acquisition of analytical skills (draw conclusions), and therefore the sense of responsibility for the decisions. The so understood training drew attention M. Horkheimer (2011): „After this shortcuts that recently occurred, and in spite of its, I cannot abandon the hope that not only in the first period after the disaster and in the coming decades this forgotten already attitude is again the aim of university-level education. Limitation of study to acquire skills (...) is not enough. The judge deprived empathy means death of justice".

With this in mind, training is a condition of the spirit, which remains even when forget about all acquired all competence.

However there are two main obstacles in the way of the so understood education. As can be observed, currently training is connected mainly with the process of absorption. Whereas the obstacle (the instructor), how stated one of my students on the exam with the insurance: why the lord, o Lord he requests from me such knowledge. I have it in hard memory? In response heard of me: ,this knowledge, which is contained in a hard memory is not your knowledge, known by Mr purposeful. It is not part of the Lord. This is not data media (PCS) must be fitted with an expected my knowledge, but the Lord must be developed.

The second obstacle results from the increasingly stronger differences between the world of the spirit that requires work and the world of changing successively technology, which causes us to get fired from this job. Contemporary 
globalisation process and the changing world of technological developments that is civilization many simplifications, contributes significantly to laziness. Technological changes that give rise to the „Youth technical” must be followed by wisdom - life wisdom. Already I. Kant (1986) wrote that the wisdom of life is: „, no authority recognition is properly what we call stupidity and this troubles cannot be remedied. Head knife back or limited, whose absence of sound level common sense and its own concepts can be very well equipped know even. But since then usually lack of hint of wisdom (seconds Petri), this is not surprising that meets very scholars people who in the application of its science often disclose this lack not measurable repair".

The main purpose of this paper is to examine the relationship between the level of individuated customer knowledge and the quality of customer service in the motor insurance sector using the Servqual method. Based on the above objective, the author has accepted the thesis that knowledge is an important factor influencing the increase of quality of services provided in the motor insurance sector. The article uses the knowledge contained in the literature and the results of the statistical survey on a selected group of customers using the service offer of insurance institutions on the territory of Podkarpackie and Lubelskie Voivodeships in the years 2015-2016.

\section{Knowledge of the Subjective and Objective}

In the knowledge of an objective shall take into account the things „true”. This knowledge is at the same time their own good and general. Is above all - rationalism in providing all the information (not „sell”) knowledge based on objective defined data. This knowledge, does not bear the characteristics of the emotional, flowing from inside the unit. The person providing knowledge objective - directs the justice and true reality (ref. Popper 1992) ${ }^{2}$. However, whereas the subjective knowledge, the person providing the information has its prejudices, personal respects, experiences, liabilities stemming from the inside. This knowledge is ,unilateral” - often incompatible with the assessment of reality (Table 1). In the case of secondary schools or universities (Busom, Lopez-Mayan, Panadés, 2017), basic media knowledge is teacher or lecturer at universities who have both subjective knowledge (not available), or individual, difficult to formalise and objective (non-confidential).

Table 1. Knowledge subjective and objective

\begin{tabular}{|c|c|c|}
\hline & Knowledge implicit (hidden, not available) & Knowledge evident (available) \\
\hline$\frac{\stackrel{8}{0}}{\stackrel{0}{0}}$ & $\begin{array}{l}\text { - individual - difficult to copy, } \\
\text { - leaves the inside of us (on experience), } \\
\text { - focus (used by many people in many places at once) - } \\
\text { here and now, } \\
\text { - subjective, } \\
\text { - whizz (analogy) - practice. }\end{array}$ & $\begin{array}{l}\text { - intersubjective (available for more than one company) - easy } \\
\text { to transfer, } \\
\text { - knowledge on the outside of the US (leaves the rational } \\
\text { understanding), } \\
\text { - sequential - there and then, } \\
\text { - objective, } \\
\text { - theory. }\end{array}$ \\
\hline
\end{tabular}

Source: based on (ref. Nonaka and Takeuchi 2000).

Characteristics of knowledge an open and hidden were I. Nonaka and H. Takeuchi [2000, p. 84). They wrote of the mutual relations between them. They considered that the knowledge the implicit is by way of communication. A process that requires a kind of distributed processing approaches as individual skills, experience, information theoretical and practical, i.e. competence communication sender.

Knowledge available, so-called excepted, is transmitted in the form of information using a variety of data sources, which is facing the theory outside the text. Provides the knowledge in the education process is created in a spiral [Nonaka and Takeuchi 2000, p. 96], where processes: socialisation internalisation combination and externalisation complement each other and are, in the cycle of transmission and processing of the information that a new knowledge students or students. De facto they generate new knowledge by using the process of interaction with/or lack of practical training. Harmonisation of knowledge explicitly is the end of the process of reaching the expected knowledge (truth) about the new topic (subject) - its sources of origin.

\footnotetext{
${ }^{1}$ All studies, analyzes and conclusions are authored by dr. J.W. Przybytniowskiego

${ }^{2}$ According to this author, scientific rationality is unambiguously connected with the way science evolves, in view of adopting a critical attitude towards the emerging theories. According to this theory, all your efforts should be directed towards creating new theories to falsify the predictions, rather than lead to another confirmation of verification. Only constantly criticized and questioned knowledge has come up, it can lead to systematic creation of the more perfect theories, because sometimes what we see nowadays, it can be ,we were wrong” and consequently we can learn from our own mistakes and draw conclusions. Admit - we made a mistake.
} 


\section{Knowledge and Level Of Quality Insurance Motor Services}

Creating the broad fundamentals of knowledge, i.e., the resource essential for the scientific discovery of thinking models (consciousness) or highly abstract concepts, is becoming the basic object of making rational strategic decisions in a company, and is an important source of development of key competencies in the market of services. Concentration on narrow fundamentals of knowledge has its application in the areas of dynamically developing economic reality (Mikuła, Pietruszka-Ortyl \& Potocki, 2002), which builds up a permanent competitive advantage (Brdulak, 2005) in the service sector, maintained in a long time horizon. Contrary to the concentration, knowledge diversification aims at multiplying a wide range of skills to use it in the future. It enables the organisation to avoid the negative consequences of "aging" and, hence, quick reaction to uncertainty and changes undergoing in the company environment (Przybytniowski, Buczma, 2014). This important contribution of academic circles into defining the knowledge factor has become the basis for multidisciplinary academic analyses from various research perspectives. How complex and ambiguous the concept of knowledge is, becomes clear as there are a number of definitions and synthetic presentations included in the Polish literature (Oleński, 1997; Drucker, 1999; Amstrong, 2001; Kisielnicki, 2003; Mikołajczyk, 2003; Koźmiński, 2004; Galata, 2004; Mikuła, 2005; Stankiewicz, 2007; Koźmiński, Jemeiniak, 2007; Golińska-Pierzyńska, 2009; Skrzypek, 2009; Beliczyński, Mesjasz, Stabryła, 2009, Pacholarz, 2016). The Authors pay particular attention to the necessity of considering the knowledge factor in the reality surrounding us. The level of capabilities developed by an individual contributes to the growth of the company image quality, thus allowing for solving problems, developing proper attitudes/behaviour, and winning the competitive position in its environment. The above deliberations on knowledge are to be continued by presenting the definitions adopted by academics in the foreign literature, where the immateriality of the factor of knowledge is emphasized in qualitative terms (Nonaka \& Takeuchi, 2000). Individual persons having at their disposal a certain degree of knowledge in their actions, make conscious and rational decisions, which enables them to achieve success. The Authors (Nonaka, Takeuchi, 2000) claim that knowledge is "work on one's own self, the knowledge of developing skills, using one's own assets and increasing one's opportunities in the social learning processes".

With this in mind, knowledge has in its essence important attributes aspects of social life. Knowledge it includes in itself important attributes which are crucial aspects of social life. It has cognitive and practical value related to the phenomena surrounding us, viewed in terms of information and set in a proper context, which enables a human being to act efficiently and effectively by continuous improvement. Moreover, the general expression of perfectness becomes one of the elements of the productive use of knowledge and supply of unique values, whose essence is the level and the course of the process of insurance service quality.

\section{Customer Knowledge of Individual Quality Insurance Motor Services}

The quality of service provision depends largely on several aspects:

1) Existing legal regulations regulating the analysed problems.

2) Transparency of procedures connected with the key skills of customers using the services.

3) Competences of the staff entering into direct contact with customers.

One of the conditions of positive changes in the sphere of service quality is making any changes and pursuing solutions which support building positive relations with customers while fulfilling their needs. Quality in the process of customer service is defined as a set of features characteristic for the goods or services during their acquisition, which contribute to meeting the needs of customers (Stoma, 2012). In the terminology of customer service-related processes, the concept of quality is connected with the assessment of how goods or services will contribute to the satisfaction gained by a customer. In practice, the quality of goods or services is often identified with meeting customer requirements. The problem of quality in relation to a customer is considered in three dimensions (compare: Zeithaml, Bitner, 2002):

1) Quality of basic product or service.

2) Technical service during the sales transaction.

3) Extended service.

The first two elements refer only to the product and the technical side of the transaction, whereas the third element (extended service) refers to the direct contact with a customer. A similar approach is presented by K. MazurekŁopacińska (1997), where quality is considered in two levels. The first level refers to technical requirements of a product, while the second level includes the development of quality in all the stages of contacts with a customer. Hence, the important role on broadly understanding customer service is played by communication. We can assume that product quality is connected with the element of service and communication, which is linked with the customer having adequate knowledge and awareness accompanying it. Customer awareness is closely connected with the element of knowledge possessed. This factor has an impact on making rational choices by a customer at the moment of buying a service, as well 
as creating a positive image of an organisation. Building consumer awareness is a long-term process, and the most effective tool is knowledge and education. Consumers equipped with knowledge are ready to pursue their needs and introduce conscious changes into the quality of offered services. Being aware enables to optimise service utility for the customer, and also offers an opportunity for an organisation to efficiently distinguish itself from others, which is connected with high prestige.

\section{Evaluation of the Quality of Motor Insurance Services through of the SERVQUAL Method}

The methodology in this paper is using the Servqual method to research and analyse the assessment of insurance service quality . The Servqual method is used to examine the level of service quality and customer expectations, and their sensitivity to change while providing a certain service. It is used as a universal measure in the examination of quality of all kinds of services. The application of Servqual method lets us know customer expectations and examine the gap between what a customer expects and what a customer is given by a service provider (Hamrol \& Mantura, 2008). The purpose of the research is to analyse the relation between the buyer's expectations and mental representations, and the way the service is perceived by the buyer, bearing in mind the optimal level of possessed knowledge and awareness, using five Servqual factors (areas). In order to reach the assumed aim and achieve objective research results, the Author uses the results of statistical data and the literature, which allows to adopt definite factors (areas) in the service quality assessment by means of the Servqual method. In order to establish the attributes of insurance service quality and express the opinion on the analysed issue, a questionnaire survey was conducted among individual customers using the services of insurance institutions Podkarpackie and Lubelskie Province from October to December in the years 2015-2016. The survey was conducted by insurance agents being in direct and indirect contact with customers of an insurance institution. Customers of insurance institutions were supposed to present their subjective opinion on the service offered to them. Moreover, they presented their opinions in two areas: the service expected and the assessment of the service experienced. By means of the Servqual method the level of customer satisfaction was examined, the satisfaction with the use of services provided by insurance institutions in the two provinces. In order to determine the assessment of importance of five attributes of quality (service tangibility, reliability, empathy, professionalism and confidence, and the reaction to customer expectations), and to examine customer opinions in terms of the insurance service offered, the author applied a 7-point scale, where "1" - means very poor (insignificant), and "7" - means excellent (very important). The assessment of insurance service quality was to calculate the difference between customer expectations and the service perception. It allowed the Author to find the gap between these values and to indicate the areas in which it is necessary to introduce additional changes and remedial actions. The analysis of the research results was divided into three stages:

1) Establishing the differences between consecutive expectations and experiences expressed in points.

2) Calculating the average difference in points in each of the analysed areas.

3) Using the Servqual method to calculate the total arithmetic measure of quality of the service examined.

The questionnaire consisted of 12 questions, 4 of which referred to general and sociodemographic issues. Stratified sampling was applied. The base for the strata were statistical data of the Main Statistics Office from the 2015 and 2016 census, related to the residence of the customers polled.

The survey was conducted on a group of 150 respondents, of whom, following the initial verification:

1) in Podkarpackie Province in 2015 -, 119 (79,3\%) respondents were qualified, while in 2016 the number of respondents was $123(82 \%)$;

2) in Lubelskie Province in 2015 - 137 respondents (91,3\%) were qualified, while in 2016 - 134 respondents (89,3\%) were qualified.

The detailed data on the groups of respondents are included in Table 2.

Table 2. The structure of respondents in Podkarpackie and Lubelskie Province in the years 2015-2016 (in numbers $\mid \%$ )

Source: Based on statistical data

\begin{tabular}{|c|c|c|c|c|c|c|c|c|}
\hline Criterion & Podkarp & ackie Pro & vince & & Lubelskie $\mathbf{P}$ & rovince & & \\
\hline Years & 2015 & & 2016 & & 2015 & & 2016 & \\
\hline No. of respondents & 119 & & 123 & & 137 & & 134 & \\
\hline & Town & Village & Town & Village & Town & Village & Town & Village \\
\hline Place of residence & $\begin{array}{l}71 \\
(59.7 \%)\end{array}$ & $\begin{array}{l}48 \\
(40.3 \%)\end{array}$ & $\begin{array}{l}69 \\
(56.1 \%)\end{array}$ & $\begin{array}{l}54 \\
(43.9 \%)\end{array}$ & $82(59.9 \%)$ & $55(40.1 \%)$ & $85(63.4 \%)$ & $49(36.6 \%)$ \\
\hline
\end{tabular}

\section{Research and Analysis of the Assessment of Insurance Service Quality in Podkarpackie Province}

Insurance service quality in Podkarpackie Province was examined by means of the 5 -factor scale of the Servqual 
method, in which the factors (areas) are used to assess the level of insurance service quality in the opinion of customers of insurance institutions (Figure 1). For customers of Podkarpackie Province, in 2016 the average value for all the areas of insurance service quality was at the level of (-2.15), in comparison with 2015 , where the total average in all the quality areas was (-2.12), which means that customer preferences, influencing the increase in expectations in terms of insurance service provision, were not fully met, while the service quality level was unsatisfactory. The data acquired in during the first stage of the survey indicate a gap between expectations and experiences of customers of insurance institutions in all the dimensions of quality.

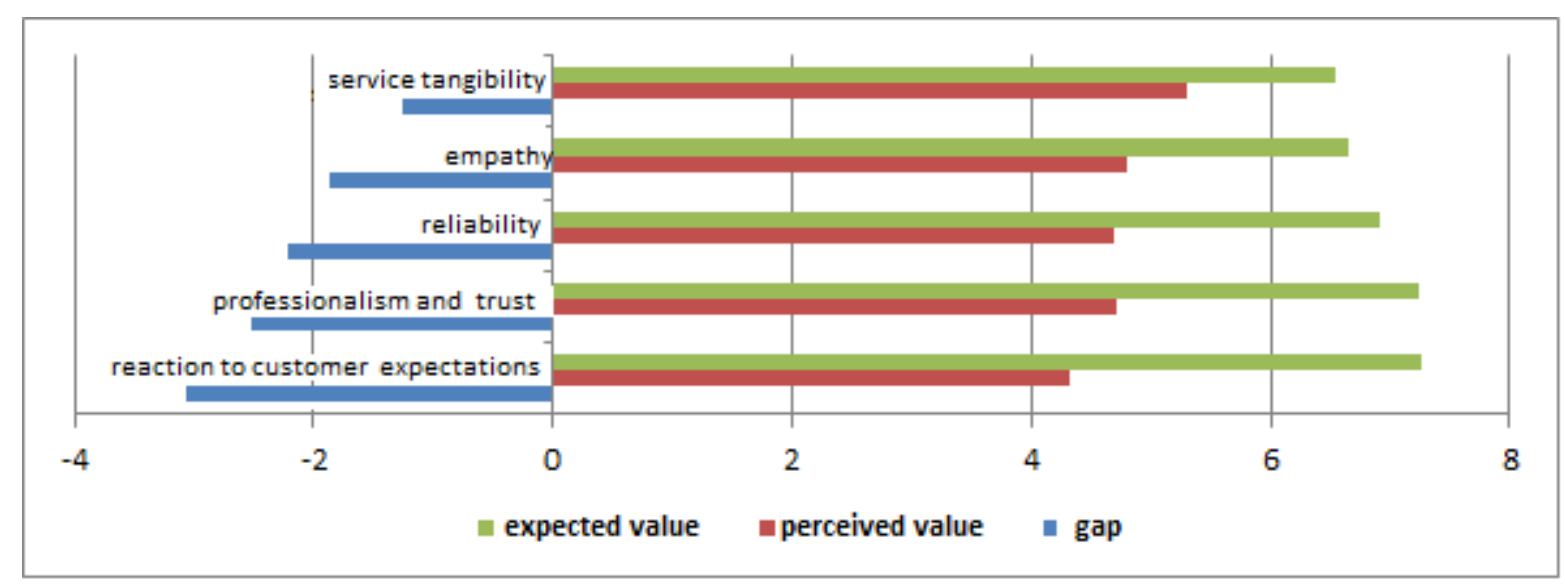

Figure 1. The level of insurance service quality in the opinion of customers of insurance institutions in Podkarpackie Province

\section{Source: Based on statistical data}

The above figure shows that of the above quality dimensions, an important attribute in direct contact with customers during the process of service provision is the tangible dimension of the activity of insurance institutions $(-1,27)$. During the studied period, of all the studies areas, the lowest level showed such factors as: reaction to customer expectations, professionalism and confidence, and reliability. These areas of quality recorded the greatest differences, which lets us claim that the level of quality of insurance service provision is at a low level, while customer expectations towards the studied insurance are not fulfilled. Analysing statistical data in terms of the weighted average for each of the dimensions of insurance service quality and the weighted average of insurance service quality, it can be considered that the most important area for the respondents was the reaction to customer expectations, while the least important was the tangible area. Bearing in mind the importance of the analysed quality dimensions for the customers in Podkarpackie Province in 2016 , the total weighted average of the level of quality amounts to $(-0,42)$, which indicates a low service quality and, consequently, the lack of fulfilment of customer expectations during the process of buying the service. Similar results were acquired in arithmetical average - in 2015 the highest weighted result: the reaction to customer expectations $(-0,69)$ and the lowest result in the tangible area $(-0,24)$, show the low level of service provision and also the dissatisfaction of customers with the insurance offered. The results of the analysis of the weighted average of the Servqual areas are presented in Figure 2.

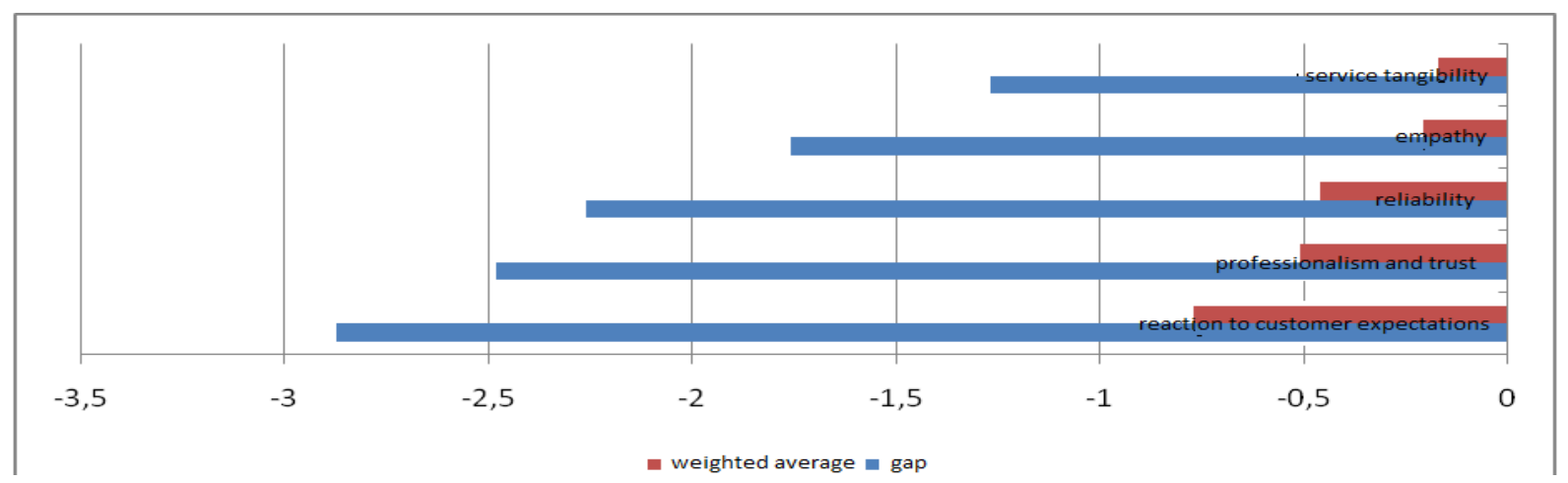

Figure 2. The level of quality of insurance services provided by insurance institutions in Podkarpackie Province in 2016, according to the measures: gap and weighted average

Source: Based on as in Figure 1 
While assessing the insurance service quality in the opinions of customers, the paper also included the criterion of place of residence of studied respondents (see: Table 3). The place of residence has a considerable impact on the accessibility of knowledge in terms of getting to know the insurance services provided by insurance institutions, thus, it contributes to the increase in customer awareness. In all the research groups, the arithmetic average reached a negative result. Moreover, the total result in all the areas of insurance service quality provided by insurance institutions was at a negative level, which is presented in Figure 3.

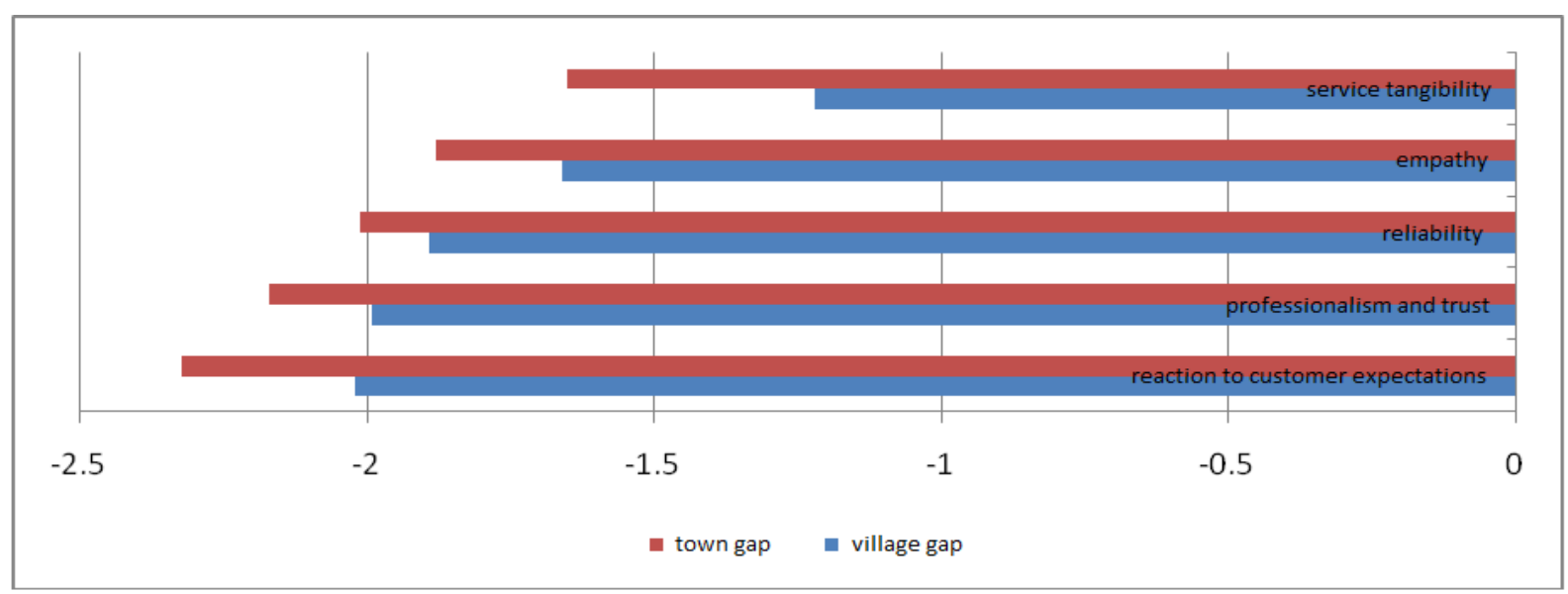

Figure 3. Assessment of insurance service quality among people residing in towns and villages in Podkarpackie Province in 2016

\section{Source: Based on as in Figure 1}

Analysing the group of respondents residing in towns in Podkarpackie Province in 2016, the arithmetic average in all the studied areas was $(-2,01)$, compared to 2015 when the average was $(-2,00)$. The above results clearly confirm the opinions of respondents living in towns. In the opinions of the studied group of customers residing in towns in Podkarpackie Province the following factors: professionalism and confidence, reaction to customer expectations, reliability and empathy were at the lowest level (in 2015).

In case of people residing in towns in Podkarpackie Province, the average Servqual result in 2015 was $(-2,00)$ and in 2016 was $(-2,01)$, which is lower than the general average which reached in $2015(-2,12)$ and in $2016(-2,15)$. It shows that studied respondents feel the lack of satisfaction with the service bought and confirms the fact that the level of insurance service provision is at a low level and does not meet customer expectations.

Analysing the next group of respondents residing in villages in Podkarpackie Province, the average difference of dissatisfaction between customer experiences and expectations in terms of offered insurance services was assessed in 2015 at the level of $(-1,90)$, and in $2016(-1,76)$, which shows that, like in case of people residing in towns, the level of insurance service offered brings unsatisfactory results. Assessing the process of service quality provision, the arithmetic average for both studied groups (town and village) in Podkarpackie Province was $(-2.00)$ in 2015 and in $2016(-1,88)$. This situation indicates a growing dissatisfaction with the quality of offered services among the respondents residing in villages in Podkarpackie Province. Comparing the two studied groups in the years 2015-2016, in terms of experience and expectations of the service provided, only in the area of "reliability" the results are similiar. The greatest differences were recorded in the area of "service tangibility".

\section{Research and Analysis of the Assessment of Insurance Service Quality in Lubelskie Province}

In order to compare the results of the research conducted in Lubelskie Province, the Author analysed and examined the customers using the service offer of insurance institutions in Lubelskie Province. As indicated in Figure 4, in 2016 the average value of individual areas of quality reached $(-2,15)$ while in 2015 the total result amounted to $(-2,28)$. 


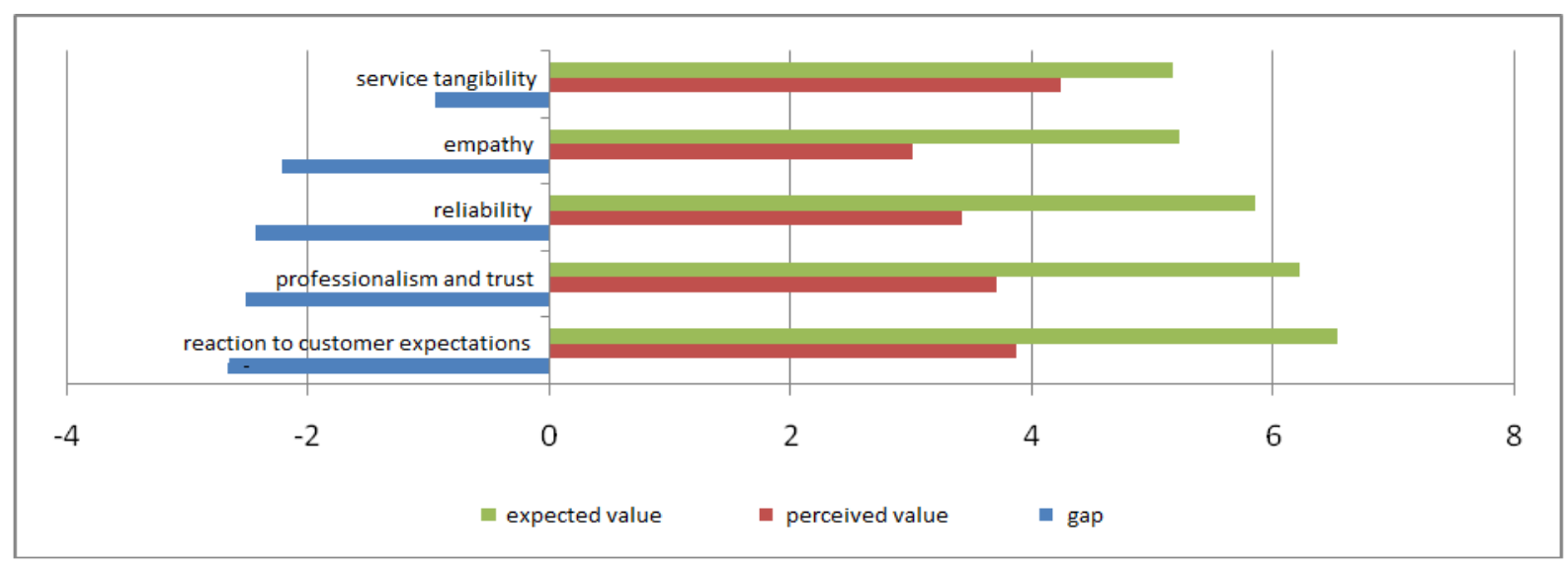

Figure 4. The level of insurance service quality in the opinion of customers of insurance institutions in Lubelskie Province

\section{Source: Based on as in Figure 1}

The most favourable result of all the studied quality areas was achieved by the service tangibility $(-1,42)$ in 2015 . It indicates that insurance institutions generally think that the tangible aspect of their activity (employees' attractive appearance) is the main attribute in contacts with customers and it determines whether the insurance contract is executed. In the opinions of studied respondents, the lowest quality was shown in the following areas: reliability, professionalism and trust, and the reaction to customer expectations. In the listed areas, there were the greatest differences noted, which allows to claim that the level of insurance service quality is at a low level, and customer expectations are still not fulfilled.

The next stage of the research was to calculate the weighted average of the level of the insurance service quality in each of the studied areas. An important area for the studied respondents was the reaction to customer expectations, while the tangibility of the service was of slight significance. Bearing in mind the importance of studied dimensions, in 2016 the total average measure of insurance service quality amounted to $(-0,49)$. To compare, the weighted average of the level of insurance service quality was $(-0,54)$ in 2015 , which indicates a low level of services, as well as the failure to meet expectations of potential customers (Figure 5).

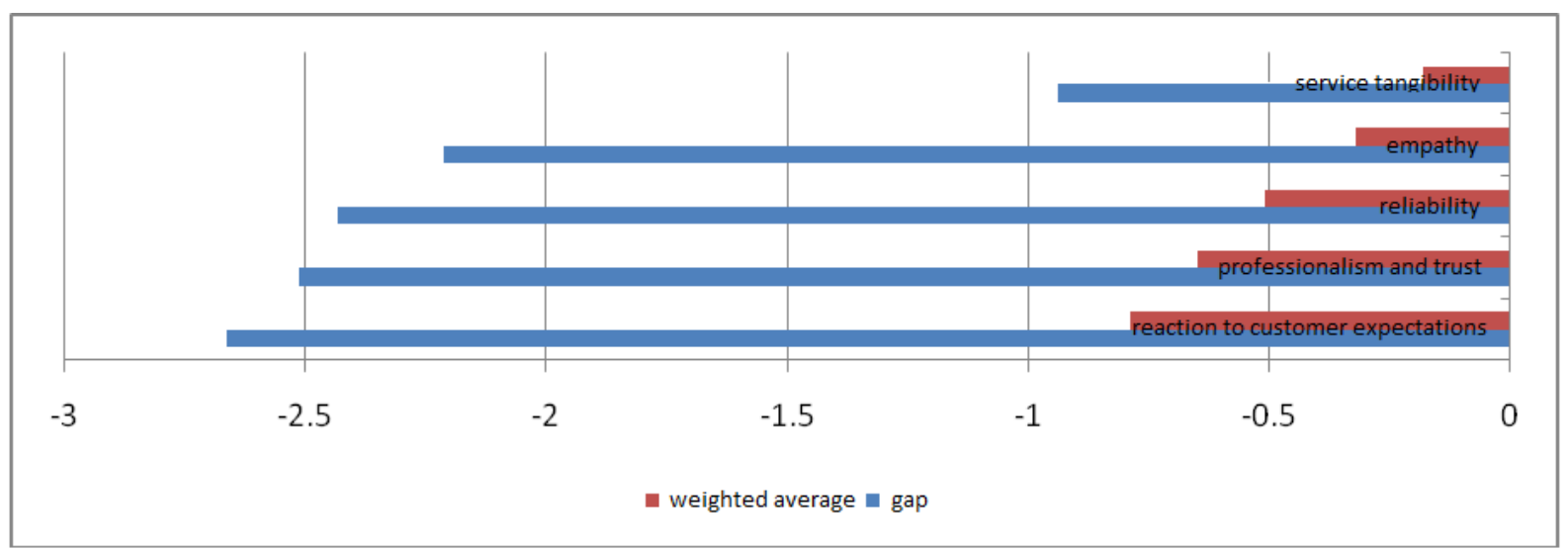

Figure 5. The level of quality of insurance services provided by insurance institutions in Lubelskie Province in 2016 , according to the measures: gap and weighted average

\section{Source: Based on as in Figure 1}

Studying the respondents in towns in Lubelskie Province, the arithmatic average was (-2.96) in 2016, while in 2015 the average value in all the studied areas was (-1.99), which seems to be justified by a clear growth trend in the quality of service provided by insurance institutions (Figure 6). 


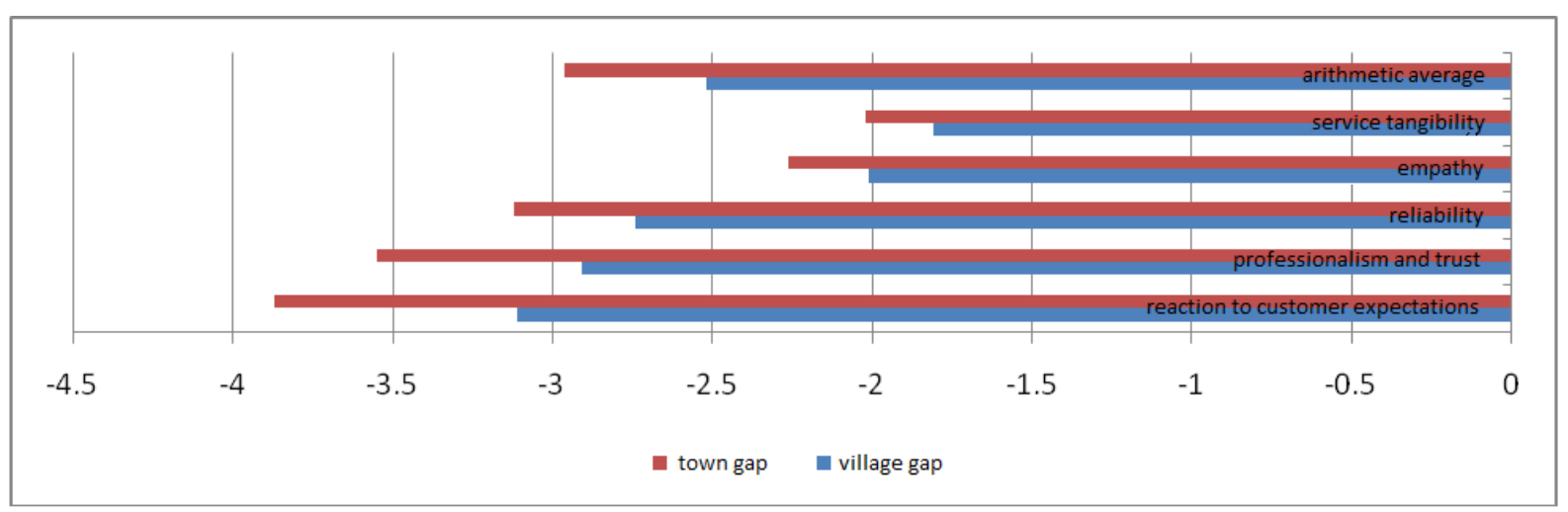

Figure 6. Assessment of insurance service quality among people residing in towns and villages in Lubelskie Province in 2016

Source: Based on as in Figure 1

Among customers residing in towns in Lubelskie region, the greatest differences were noted in the following areas: reliability, professionalism and trust and the reaction to customer expectations. The average result reached by people residing in towns in 2016 is higher than the general average result, which indicates that town residents feel more dissatisfied with the insurance studied and the level of the service provided is still at the low level, Studying the people residing in villages, the average difference between customer experiences and expectations in terms of the service provided was in $2015(-2.53)$ and in $2016(-2.52)$, which indicates that the quality of the service provided still brings unfavourable results. Assessing the process of service quality provision, the arithmetic average for both studied groups (town and village) in Lubelskie Province was at the level of (-2.26) in 2015 and (-2.74) in 2016. This situation shows dissatisfaction of the respondents living in villages. Comparing both research groups in the years 2015-2016, in terms of experience and expectations of the service provided, only in the area of "empathy" and "reliability" the results are similar. The greatest differences were noticed in the area of "the reaction to customer expectations" and "professionalism and trust".

\section{Analysis of Knowledge in Studying the Level of Service Quality on the Basis of Podkarpackie and Lubelskie Provinces}

The growing customer awareness (Rogoziński, 2000), the increasing possibilities of migration and the quickly-changing trends, cause that the key factor enabling to achieve success is meeting the expectations, adjusting the standards and quality of customer service to customer requirements. Building loyalty among customers and actions intended to reduce retention to keep the customer pose quite a challenge. Customers form their requirements on an ongoing basis, therefore, the information on their preferences should be regularly collected, then skilfully selected, as well as limited to the number under control and translated into technical parameters. This results from the acquired communications and knowledge about customer requirements. Knowledge is a structural element of modern institutions, which emphasises its key character in management processes (Bratnicki, 2000). The revision of knowledge about customer expectations enables to adjust the quality of service provided to the current standards. The overriding factor developing the level of knowledge and key competencies of customers in the processes of service quality provision is "professionalism and trust", one of the key areas of Servqual which reflects the staff's professional knowledge and their ability to create the atmosphere of trust and confidence among customers. This factor has been analysed against other studies areas, which is presented in Table 3 .

Table 3. The analysis of knowledge in Podkarpackie and Lubelskie Provinces in the years 2015-2016, including the area of "professionalism and trust"

\begin{tabular}{lllll}
\hline \multirow{2}{*}{ Servqual areas } & \multicolumn{2}{l}{ Podkarpackie Province } & \multicolumn{2}{l}{ Lubelskie Province } \\
\cline { 2 - 5 } Reaction to customer expectations & 2015 & 2016 & 2015 & 2016 \\
Professionalism and trust & -2.87 & -2.92 & -2.96 & -2.66 \\
Reliability & -2.48 & -2.52 & -2.49 & -2.51 \\
Empathy & -2.26 & -2.22 & -2.31 & -2.43 \\
Service tangibility & -1.76 & -1.86 & -2.25 & -2.21 \\
\hline
\end{tabular}

Source: Based on the analyses conducted

On the basis of the conducted analysis of the level of insurance service quality among the customers of insurance institutions in Podkarpackie and Lubelskie Provinces, it can be concluded that customer expectations in terms of the 
insurance offer are insufficient, while the quality of service provision is unsatisfactory. The professionalism and trust factor is the second important in the process of service provision, which indicates a low level of customer satisfaction, as well as the low consciousness of the staff response to customer needs. In Podkarpackie and Lubelskie Provinces, the area of professionalism and trust does not show significant differences, although its slight growth trend may continue in the next years. It may be stated that in the areas in which there is easier access to new technologies, where the sector is dynamically developing, the value of services, as well as the level of knowledge, is reaching the level satisfying potential customers. The above results indicate a moderate difference between customer expectations and the perception of services offered in terms of individual quality areas. Thus, it may be stated that the existing discrepancies in the studied areas show a low level of satisfaction of customers with the quality of service provision. Insurance institutions, by taking action to improve insurance service quality, should possess basic knowledge about how to adjust customer expectations to the process of service quality implementation, which will allow for a positive perception of the service bought by customers.

\section{Conclusion}

As a result of the studies carried out, has been implemented. The research conducted lets form the following conclusions:

1) The level of insurance service quality is determined by certain factors which are interconnected and function simultaneously.

2) Customer knowledge of services allows for an appropriate selection of the service to be purchased, thus resulting in deeper awareness of their expectation fulfilment.

3) The development of the service sector and the potential of entities operating in the service market are becoming a key area of knowledge-based economy, which results in the growing awareness of service buyers and, thus, in rational decision-making in the process of service provision at the proper level of knowledge possessed.

4) In the studied provinces the average Servqual result and the weighted average in the studied areas were at a low level, which confirms that the level of insurance service provision is at a moderate level, which is connected with the failure to meet customer expectations.

\section{References}

Bratnicki, M. (2000). Kompetencje przedsiębiorstwa. Od określenia kompetencji do zbudowania strategii, Agencja Wydawnicza Placet, Warszawa, 37-45.

Brdulak, J. J. (2005). Zarządzanie wiedza a proces innowacji produktu. Budowanie przewagi konkurencyjnej firmy, Szkoła Główna Handlowa, Warszawa, 14.

Busom, I., Lopez-Mayan, C., \& Panadés, J. (2017). Students' persistent preconceptions and learning economic principles, The Journal of Economic Education, 48(2), 74-92. https://doi.org/10.1080/00220485.2017.1285735

Galata, S. (2004). Strategiczne zarzadzanie organizacjami. Wiedza, intuicja, strategie, etyka, Difin, Warszawa, 59.

Hamrol, A., \& Mantura, W. (2008). Zarządzanie jakościa. Teoria i praktyka, PWN, Warszawa, 9.

Horkheimer, M. (2011). Odpowiedzialność i studia, przekład translatoryjny pod kierunkiem H. Walentynowicz, Kronos, 240.

Kant, I. (1986). Krytyka czystego rozumu, t. I, tłum. R. Ingarden, Warszawa, 273.

Mazurek-Łopacińska, K. (1997). Zachowania nabywców, jako podstawa strategii marketingowej, Akademia Ekonomiczna we Wrocławiu, Wrocław, 21.

Mikuła, B., Pietruszka-Ortyl, A., \& Potocki, A. (2002). Zarządzanie przedsiębiorstwem XXI wieku, Difin Warszawa, 69-71.

Morawski, M. (2005). Zarzadzanie wiedza w perspektywie personalnej, [w:] Perechuda K. (red.), Zarzadzanie wiedza w przedsiębiorstwie, Wydawnictwo Naukowe PWN, Warszawa, 205.

Mrozowska, B. (2012). Bancassurance - regulacje prawne i samoregulacja rynku, Prawo Asekuracyjne, 3/2012(72), 30-34.

Nonaka, I., \& Takeuchi, H. (2000). Kreowanie wiedzy w organizacji, Poltext, Warszawa, 40.

Panasiewicz, L. (2002). Organizacyjne uczenie się a zarządzanie wiedza, Ekonomika i Organizacja Przedsiębiorstwa, Warszawa, 9(632), 10.

Popper, K. R. (1992). Wiedza obiektywna ewolucyjna teoria epistemologiczna, Warszawa: PWN, 52.

Porter, M. E. (2001). Porter o konkurencji, PWE, Warszawa, 192. 
Przybytniowski, J. W. (2007). Edukacja ubezpieczeniowa i jej wplyw na świadomość ubezpieczeniowa (wybrane problemy), Rozprawy ubezpieczeniowe, 1(2) 2007, Warszawa, 111-118.

Przybytniowski, J. W. (2013). Konkurencyjność rynku ustug pośrednictwa ubezpieczeniowego w Polsce, Wydawnictwo Menadżerskie PTM, Warszawa, 64-65.

Przybytniowski, J. W., \& Buczma, S. E., (2014). Edukacja i wiedza finansowa a konkurencyjność przedsiębiorstwa ubezpieczeniowego, Ekonomika i Organizacja Przedsiębiorstwa, Warszawa, 12(779), 73-74.

Rogoziński, K. (2000). Nowy marketing usług, Akademia Ekonomiczna w Poznaniu, Poznań, 22.

Rudawska, E. (2000). Rola jakości w kreowaniu lojalności klientów banków, [w:] Rogoziński K. (red.), Marketing usług profesjonalnych, Akademia Ekonomiczna w Poznaniu, Poznań, 188.

Seneka, L. A. (1961). Listy moralne do Lucjusza, thum. W. Kornatowski, Warsaw: PWN, 409.

Stoma, M. (2012). Modele i metody pomiaru jakości usług, Lublin, www.qrpolska.pl/files/file/M3.pdf., 01.05.2015.

Turowski, K. (2006). Sektor wysokiej techniki jako czynnik rozwoju kapitalu ludzkiego-implikacje dla konkurencyjności polskiej gospodarki, [w:] Kopycińska D., (red.), Kapitat ludzki w gospodarce opartej na wiedzy, Printgroup, Szczecin, 94.

Zeithaml, V., \& Bitner, M. (2002). Services Marketing, McGraw-Hill, 1966, [w:] Sangowski T. (red.), Ubezpieczenia w gospodarce rynkowej, Oficyna Wydawnicza Branta, Bydgoszcz - Poznań, 115.

\section{Copyrights}

Copyright for this article is retained by the author(s), with first publication rights granted to the journal.

This is an open-access article distributed under the terms and conditions of the Creative Commons Attribution license which permits unrestricted use, distribution, and reproduction in any medium, provided the original work is properly cited. 